\title{
Intermédialités
}

Histoire et théorie des arts, des lettres et des techniques

Intermediality

History and Theory of the Arts, Literature and Technologies

\section{(De)compositions: Time and Technology in William Basinski's The Disintegration Loops (2002)}

\section{Jakko Kemper}

Numéro 33, printemps 2019

restituer (le temps)

rendering (time)

URI : https://id.erudit.org/iderudit/1065020ar

DOI : https://doi.org/10.7202/1065020ar

Aller au sommaire du numéro

Éditeur(s)

Revue intermédialités

ISSN

1920-3136 (numérique)

Découvrir la revue

Citer cet article

Kemper, J. (2019). (De)compositions: Time and Technology in William Basinski's The Disintegration Loops (2002). Intermédialités / Intermediality, (33). https://doi.org/10.7202/1065020ar
Résumé de l'article

Cet article analyse l'album The Disintegration Loops (2002), de William Basinski, et soutient que son interprétation esthétique de la temporalité et de la finitude est pertinente au regard de la relation entre technologie et perception humaine du temps pour trois raisons. Premièrement, l'appareil technologique responsable de sa création reflète les concepts derridéens d'espacement et d'auto-immunité. Deuxièmement, l'appel affectif de l'album illustre la notion de chronolibido de Martin Hägglund. Troisièmement, la musique donne lieu à une expérience médiatique temporelle qui contraste avec l'expérience médiatique offerte par ce que Mark B.N. Hansen appelle les « médias du $21^{\mathrm{e}}$ siècle ». Ensemble, ces trois dimensions font de The Disintegration Loops un objet qui permet de donner une base empirique aux théories discutées du temps et des médias. 


\title{
(De)compositions: \\ Time and Technology in William Basinski's The Disintegration Loops (2002)
}

\author{
JAKKO KEMPER
}

$\mathrm{f}$ there is one central element that can be discerned throughout the long and heterogeneous history of technological advancement, it might very well be the unrelenting quest for efficiency - a persistent drive to have our technologies perform their designated tasks at ever greater speeds. This has culminated in the use of, for example, high-frequency trading algorithms, whose decision-making capacities play out in timescales that elude the human sensorium. As this logic of acceleration endows technology with an expanding degree of agency, it remains urgent to keep interrogating the relation between technology and the temporal, and to assess how our aesthetic experience of time is affected by shifting media conditions. How is time itself constituted and how is our lived experience of it mediated by technology?

In order to partially address these questions I will analyze how time is aesthetically rendered in William Basinski's 2002 album The Disintegration Loops. ${ }^{\mathrm{I}}$ While this album has traditionally been analyzed in view of its affective link with the traumatic events of $9 / \mathrm{II}$, I want to offer a reading that scrutinizes its aestheticization of time primarily on the level of the recording process, paying particular heed to how this process grants a phenomenological intuition of the workings of time itself. The album is relevant as an object of analysis for two reasons. First, Basinski arrived at the compositions through constructing, unwittingly, a technological apparatus from whose unique temporal logic the music emerged directly-this apparatus, I will contend, forms a material illustration of the metaphysical constitution of the

\footnotetext{
I William Basinski, The Disintegration Loops, 2062 Records, 2002.
} 
temporal. Second, the music itself - distinguished by an audible process of decaycan be said to document the intimate relation between time, desire, and finitude. I argue that both of these dimensions speak directly to the idiosyncratic way in which time is afforded a central role in the strand of media theory embodied by Jacques Derrida and Bernard Stiegler. Specifically, I will suggest that Derrida's concept of spacing, the concept of autoimmunity as philosopher Martin Hägglund identifies it throughout Derrida's oeuvre, and Hägglund's own ideas on chronolibido coalesce in The Disintegration Loops and the technological apparatus that undergirds it. Furthermore, I will argue that the temporal experience provided by Basinski's music offers a critical counterweight to the hegemonic forms of media experience generated by today's digital technologies. In the pages that follow a theoretical framework will first be established, followed by an analysis of Basinski's music through the framework's lens, and concluded by a consideration of the music's pertinence to the temporal biases of contemporary digital media. Time will be defined primarily as a specific logic that exists independently from the scaffolding of human perception, but attention will also be paid to the implications this bears for the phenomenological apprehension and aesthetic rendition of the temporal.

\section{SPACING, Autoimmunity, Chronolibido}

Jacques Derrida and Bernard Stiegler have both made indispensable contributions to the theorization of the complex relation between technology and the experience of time. Derrida's notion of différance and his elaboration of Plato's conception of the pharmakon (technology as both cure and poison) have proven conducive to attaining a clearer picture of technical evolution by conceptualizing technological inscriptions as forms of writing that have their effects on human cognition. Similarly, Stiegler's expansion of the pharmacological perspective and his linking of phenomenology and technology have demonstrated convincingly that technical objects directly affect time-consciousness. In addition to the sizable offerings that these theorists have themselves granted to the analysis of media objects, their work has also been drawn on, augmented, and revised in the context of subjects 
as varied as software studies, ${ }^{2}$ technological autonomization, ${ }^{3}$ digital biopolitics, ${ }^{4}$ and machine judgment, 5 to name but a few examples. What I want to add to this rich body of work is a consideration of some elements whose aggregation comprises a unique constellation that can be productively applied to the realm of media studies. Concretely, I am speaking of the Derridean concepts of autoimmunity and hauntology, and of Martin Hägglund's concept of chronolibido (which he derives in part from a reading of Derrida). This latter concept has been developed through literary exegeses, but, as I will suggest, also yields fruitful resources for interpreting media objects. Moreover, while the concepts of autoimmunity and hauntology have been applied to the realm of media studies in isolation, I will argue that their unification with Hägglund's concept offers a constructive framework for empirically understanding both how time is aesthetically rendered in media objects and how people are emotionally affected by such aestheticizations. Additionally, this framework provides one way to better comprehend the dominant processes that define the contemporary mediasphere.

As stated, one of the philosophers that has most thoroughly theorized the relation between time and technology is Bernard Stiegler. Stiegler ${ }^{6}$ views memory and, by extension, human time-consciousness as "originally exteriorized" and "technical from the start." 7 In effect, he develops

${ }^{2}$ Wendy Hui Kyong Chun, Programmed Visions: Software and Vision, Cambridge, Massachusetts, MIT Press, 20II.

${ }^{3}$ María del Pilar Blanco and Esther Peeren, "Introduction: Conceptualizing Spectralities," in María del Pilar Blanco and Esther Peeren (eds.), The Spectralities Reader, New York and London, Bloomsbury, 2013, p. I-27.

4 Anna Munster, "From a Biopolitical 'Will to Life' to a Noopolitical Ethos of Death in the Aesthetics of Digital Code," Theory, Culture ES Society, vol. 28, no. 6, 20II, p. 67-90, https://journals.sagepub.com/doi/Io.II77/02632764II4I7458 (accessed I4 October 2019).

5 David Golumbia, "Judging Like a Machine," in David M. Berry and Michael Dieter (eds.), Postdigital Aesthetics: Art, Computation and Design, Basingstoke, UK, Palgrave Macmillan, 2015, p. I23-I35.

${ }^{6}$ Bernard Stiegler, "Memory," in W.J.T. Mitchell and Mark B.N. Hansen (eds.), Critical Terms for Media Studies, Chicago, The University of Chicago Press, 2oro, p. 64-87.

7 Ibid. p. 67. 
[...] a theory of memory that views technicity as constitutive of life as existence, that is, as desire and as knowledge. On such a view, the process of becoming human can be characterized by the appearance of simultaneously hypomnesic [i.e. externalized] and anamnesic [i.e. embodied] epyphilogenetic memory: memory that is at once the product of individual epigenetic experience and the phylogenetic support for the accumulation of knowledge that constitutes the intergenerational cultural phylum. ${ }^{8}$

Stiegler adopts a perspective that views the phenomenological apprehension of the world by the subject as constituted through technology, thereby complicating the traditional subject/object divide. ${ }^{9}$ Technology is understood as inextricable not only from our evolution as a species, but also from our very perception of the world; Stiegler argues at length that the way we offload cognitive and perceptual faculties onto our technologies affects how we register our surroundings. Our experience of time and our ability to memorize have always been reliant on external supports - this irreducible inscription of memory onto an outside world is what Stiegler terms "tertiary retention." Io While these supports may outlast the individual or the collective (and thus facilitate communication from generation to generation), they are also perpetually at risk of being erased or altered, misinterpreted or ignored. The role that Stiegler affords to technical objects within phenomenological processes furthermore entails that if technological innovations cause media formats to change, our own experience of the world is potentially altered as well. However, before assessing how the contemporary mediasphere reconfigures temporal experience, it is instructive to first look at how time itself-regardless of its phenomenological apprehension - is logically made up, because the structure of dependency on external elements that Stiegler delineates in fact adheres to the general logic of temporality. Here, then, I will briefly bracket the question of the human experience of time in order to first address the logic of time itself. Jacques Derrida's philosophy of deconstruction offers a valuable means of thinking through the temporal.

\section{Ibid., p. 72.}

9 Bernard Stiegler, Technics and Time, I: The Fault of Epimetheus, trans. Richard Beardsworth and George Collins, Stanford, California, Stanford University Press, 1998, p. 17.

IO Bernard Stiegler. Technics and Time, 2: Disorientation, trans. Stephen Barker, Stanford, California, Stanford University Press, 2009, p. 222. 
If one were to formulate a succinct description of Derrida's project of deconstruction, Geoffrey Bennington's following assertion would be suitable: "What deconstruction affirms, what it says 'yes, yes' to, is not pure game or expenditure, but the necessity of contamination." "II Derrida's thinking functions on a fundamental unsettling of boundaries - the sustained rejection of any philosophy that presupposes the (empirical or theoretical) possibility of an entirely immutable, self-sufficient, and pure system or being. The primary reason for this is the movement of temporalization that Derrida theorizes as always already at work.

Derrida's seminal work Specters of Marx ${ }^{12}$ provides one entryway into his conceptualization of the temporal. In it, the Shakespearean motif that "time is out of joint" leads Derrida to develop his notion of "hauntology." Fundamentally, in the context of the hauntological, the contention that time is out of joint does not primarily refer to a zeitgeist that has fallen out of line and that could conceivably be made whole again provided certain political, socioeconomic, and cultural conditions are fulfilled. Rather, the observation that time is out of joint first of all speaks to a fundamental anachronism in the make-up of time itself:

If there is something like spectrality, there are reasons to doubt this reassuring order of presents and, especially, the border between the present, the actual or present reality of the present, and everything that can be opposed to it: absence, non-presence, inactuality, virtuality, or even the simulacrum in general, and so forth. There is first of all the doubtful contemporaneity of the present to itself. Before knowing whether one can differentiate between the specter of the past and the specter of the future, of the past present and the future present, one must perhaps ask oneself whether the spectrality effect does not consist in undoing this opposition, or even this dialectic, between actual, effective presence and its other. ${ }^{13}$

The suggestion that the present can never be fully contemporaneous with itself, but is always reliant on something that is other than itself, is what is registered by the

II Geoffrey Bennington and Jacques Derrida, Jacques Derrida, trans. Geoffrey Bennington, Chicago, The University of Chicago Press, 1993, p. 310.

${ }^{12}$ Jacques Derrida, Specters of Marx, trans. Peggy Kamuf, New York and London, Routledge, 1994.

I3 Ibid., p. 48, my emphasis. 
concept of hauntology: "To haunt does not mean to be present, and it is necessary to introduce haunting into the very construction of a concept. Of every concept, beginning with the concepts of being and time. That is what we would be calling here a hauntology." "I4

Now, the reason for this dis-contemporaneity is that the present is divided in itself both as a result of the fact that it passes as soon as it comes into being and because of its necessary relation to a past and a future. This division is an inherent attribute of the temporal rather than something that is imposed on it from the outside. Derrida illustrates this predicament as follows:

An interval must separate the present from what it is not in order for the present to be itself, but this interval that constitutes it as present must, by the same token, divide the present in and of itself, thereby also dividing, along with the present, everything that is thought on the basis of the present, that is, in our metaphysical language, every being, and singularly substance or the subject. ${ }^{15}$

This leads Derrida to develop his concept of the "spacing of time," alternately described as "the becoming-space of time or the becoming-time of space (temporization)." " ${ }^{6}$ The becoming-space of time entails that every moment, in order to remain, must inscribe itself as a trace onto a support, thereby spatializing itself. The becoming-time of space designates that space is not given in itself, but is related to the past and future; space is what remains over time, and a trace is left not to be apprehended at the precise moment of inscription (this would defeat the entire purpose of the trace), but at a later moment in time. This opens the trace up to exteriority; as the future is uncertain, a trace remains susceptible to all manners of calamitous contingency (erasure, destruction, misunderstanding, obsolescence). Derrida suggests that as a result of spacing "each element appearing on the scene of presence, is related to something other than itself' ${ }^{\prime \prime 7}$ and thereby never fully resistant to alterity. This also extends to Stiegler's notion of tertiary retention - the material

\footnotetext{
${ }^{14}$ Ibid., p. 202.

is Jacques Derrida, "Différance," Margins of Philosophy, trans. Alan Bass, Chicago, The University of Chicago Press, 1982, p. I3.

${ }^{16}$ Ibid.

17 Ibid.
} 
supports of memory are themselves conditioned by spacing and so nothing guarantees their durability.

It is, in other words, this movement of spacing that marks time's fundamental disjointedness and that is responsible for the necessity of contamination. Consolidating these claims, Martin Hägglund, in an incisive analysis of Derrida's work that further excavates its temporal dimensions, gathers variegated strands of Derrida's thinking under the rubric of autoimmunity. ${ }^{18}$ Autoimmunity, Hägglund explains, is a logic at work throughout the entirety of Derrida's deconstructive endeavours and it suggests that, because the spacing of time is irreducible, everything is always already threatened from within itself. ${ }^{19}$ Because the movement of spacing is constitutive of all that exists and can be thought, there is nothing that can transcend the temporal and thereby defy the possibility of corruption: "To think the trace as an ultratranscendental condition is thus to think a constitutive finitude that is absolutely without exception. From within its very constitution life is threatened by death, memory is threatened by forgetting, identity is threatened by alterity, and so on." ${ }^{20}$ In Derrida's own words, this logic of the trace is "more primordial than what is phenomenologically primordial," ${ }^{21}$ meaning that it cannot be reduced to a function of the human mind.

That this condition in turn informs human consciousness is exemplified in the way that Hägglund summarizes Derrida's refutation of certain aspects of Edmund Husserl's theory of time-consciousness. Derrida primarily takes issue with Husserl's conception of the living-present, which presupposes the existence of a pretemporal and primordial self-consciousness. Against this, Derrida argues that it is the irreducible structure of the trace that ensures that the temporal, characterized by its disjointed nature, provides the condition of possibility for any form of consciousness and presence: "Does not the fact that this bending-back is irreducible in presence or

${ }^{18}$ Martin Hägglund, Radical Atheism, Stanford, California, Stanford University Press, 2008. Derrida began using the term "autoimmunity" only in his later work, but one of Hägglund's main arguments is that the logic of autoimmunity in fact can be discerned throughout the whole of Derrida's writings.

I9 Ibid., p. 9.

${ }^{20}$ Ibid., p. I9.

${ }^{2 \mathrm{I}}$ Jacques Derrida, Speech and Phenomena, trans. David B. Allison, Evanston, Illinois, Northwestern University Press, 1973, p. 67. 
in self-presence, that this trace or différance is always older than presence and procures for it its openness, prevent us from speaking about a simple self-identity im selben Augenblick?" ${ }^{22}$ Derrida thus deconstructs Husserl's thought, showing the untenability of any indivisible unity that would be fully given to itself and that would require no moment of mediation when intending itself. Hägglund cogently captures Derrida's argument by stating that "the structure of representation is the condition for the identity of the self from the first inception. The subject can never be given in an autonomous presentation, but is constituted by relating to itself as an other." ${ }_{23}$ The structure of representation, in other words, disallows the subject full unity, meaning that self-consciousness is always already riven by temporality and therefore amenable to alterity. To this extent, Derrida's deconstruction of Husserl is symptomatic of the general logic of autoimmunity that Hägglund distinguishes throughout Derrida's work. The spacing of time and time's fundamental quality of being out of joint guarantee, on all levels, an ineluctable exposure to the risk of contamination, something that Husserl's living-present fails to register.

This quandary, moreover, is presented by Derrida and Hägglund not only as inescapable, but even as desirable. The spacing of time and the logic of autoimmunity it engenders, through the introduction of the threat of contamination and destruction, also form the condition for the good to happen and the source from which desire springs. The opening to violence is also the opening to prosperity. Derrida hints at this when he speaks of "the worst violence, the violence of the night which precedes or represses discourse," ${ }^{24}$ suggesting that the realization of the ideal to eradicate all violence would, in fact, entail an eradication of the temporal, which would remove the basis for anything (the bad and the good) to happen. Similarly, in conversation with Stiegler, Derrida questions the desire for purity, again implying that true purity would not only be impossible, but also undesirable because nothing

${ }^{22}$ Jacques Derrida, "Signs and the Blink of an Eye," in Douglas L. Donkel (ed.), The Theory of Difference: Readings in Contemporary Continental Thought, Albany, New York, State University of New York Press, 200I, p. 242.

${ }^{23}$ Hägglund, 2008, p. 65.

24 Jacques Derrida, "Violence and Metaphysics," Writing and Difference, [1967], trans. Alan Bass, London, Routledge, 1978, p. I46. 
at all could take place anymore. ${ }^{25}$ Hägglund fortifies these Derridean arguments in Radical Atheism, and in his subsequent book Dying for Time ${ }^{26}$ further traces their implications in order to ground the idea of desire even more explicitly in the temporal. This culminates in his concept of chronolibido.

Chronolibido, which merges the notions of chronophobia and chronophilia, postulates that all desire is essentially a desire for the mortal, for the finite. Hägglund begins his argument by repeating the observation that time is in its very nature disjointed: "Every moment must negate itself and pass away in its very event. If the moment did not negate itself there would be no time, only a presence forever remaining the same." ${ }^{27}$ This recalls us to the structure of the trace and of spacing, which designates that everything is inherently temporal and that nothing can fully coincide with itself. Hägglund proceeds to argue that this irreducible temporalization produces a co-implicated logic of chronophobia and chronophilia. Chronophobia indexes the fear that whatever one desires may be lost or may be changed irreversibly. Chronophilia, conversely, signals a fundamental and irrevocable attachment to the temporal..$^{28}$ That an object I desire can be lost is a consequence of the movement of temporalization, but the very structure of desire itself is also thoroughly temporal. It is only because something can be lost that one can desire it, and thus one desires it as mortal. That a moment passes forms the very condition from which desire can flow. Loss and desire are thus inextricable. "The condition of chronolibido," Hägglund concludes, "cannot be cured; it is rather the source of both hope and despair, compassion and aggression, protection and exposure." ${ }^{29}$

Hägglund is quick to note that this constitutive link to the temporal in itself does not guarantee a particular form of investment: "This tracing of time marks a minimal bond at the heart of experience. Through the structure of the trace one is bound - as a condition of possibility for any experience at all — to a past that precedes one and to a future that exceeds one. This passive bondage, which precedes any act of

${ }^{25}$ Jacques Derrida and Bernard Stiegler, Echographies of Television, trans. Jennifer Bajorek, Cambridge, UK, Polity Press, 2002, p. 134.

${ }^{26}$ Martin Hägglund, Dying for Time, Cambridge, Massachusetts, Harvard University Press, 2012.

27 Ibid., p. 3, italics in the original.

28 Ibid., p. 9.

29 Ibid., p. 167. 
will, is in turn the condition for any active libidinal binding." $3^{\circ}$ The content of this libidinal binding can take shape irrespective of the minimal bond and may thus take whatever form (be it destructive or compassionate). However, through a careful reading of the works of Marcel Proust, Virginia Woolf, and Vladimir Nabokov, Hägglund demonstrates the distinct pathos to which the condition of chronolibido can give way when aesthetically rendered. In lieu of critics that recognize in these authors a desire to transcend time, Hägglund suggests that it is the experience of and attachment to mortality that lends their writing its affective traction. Each of these authors, in his or her own way, stages the drama of being attached to life precisely because it can be lost. In this regard, chronolibido is similar to the concept of autoimmunity insofar as both indicate an openness to alterity at the heart of all things, and inasmuch as both explicate that this is a desirable state of affairs. That chronolibido, furthermore, is capable of informing intensified experiences of temporality becomes clear from Hägglund's following statement: "The most intuitive experience we have of perceptual vivacity and intensity is when we see something we love for the last time. When it is on the verge of being lost, it appears as all the more precious and as something I have to hold onto all the more." ${ }^{3}$ When the faculty of chronophobia is activated (something we care about is threatened), the flow of chronophilia can potentially intensify (we wish to hold onto it in its mortal state). Chronolibido, then, offers a perspective that allows one to analyze cultural objects in terms of the aesthetic dramatization of the spacing of time and autoimmunity. A perspective, moreover, that is sensitive to how mortality and finitude are logically woven into all forms of existence and experience.

So far, I have oscillated between defining time as the extra-human logic of spacing (i.e. spacing exists before and autonomously from any potential regimentation by human subjectivity) and exploring how this all-pervasive condition extends to technological inscription, to human consciousness, and to human desire. In order to pave the way for my reading of William Basinski's The Disintegration Loops, allow me to briefly signal two separate understandings of time that will be important. Whereas, up until now, I have been mostly concerned with mapping out the logic of spacing and with the chronolibidinal implications contained in the

${ }^{30}$ Ibid., p. I47, italics in the original.

${ }^{31}$ Michael W. Clune and Martin Hägglund, "Time in Our Time: Clune and Hägglund Debating at Stanford," CR: The New Centennial Review, vol. 15, no. 3, 20I5, p. I20, https://muse.jhu.edu/article/608960/pdf (accessed 25 March 2019). 
opening to alterity that it announces, I will from here on engage with two distinct temporal scales: one in which time is directly bound to human experience and one in which technology functions in non-phenomenologizable territories. In my analysis of Basinski's piece, I will scrutinize how time is presented phenomenologically to the listener. In the concluding section, however, I will primarily consider the speed of technological processes that, as will become apparent, take shape outside and are often even inaccessible to humanity's conscious perception of time. It is crucial to keep in mind that both of these approaches to time are defined by the logic of spacing-whether one speaks of time as it is phenomenologically apprehended or speaks of time as it cosmically flows (unconnected to consciousness), spacing remains the constitutive condition. In what follows I will argue that William Basinski's album The Disintegration Loops provides a dramatic enactment of the concepts of spacing, autoimmunity, and chronolibido and that it furthermore offers a productive avenue for thinking the temporal in an era marked by the stark acceleration of digital processes.

\section{The DisintegRation LOOPS}

William Basinski is an American composer whose output spans three decades and whose modus operandi has largely consisted in the manipulation of tapes. His music is usually marked by the presence of hiss, static, and crackle. These effects betray a persistent resistance to definition that adds to the melancholic qualities of Basinski's often plaintive melodies. Significantly, in light of this paper, Basinski recognized early on the "rich well of melancholy" 32 that could be tapped through tampering with a recording's temporality, and this interest in the modulation and rendering of time has remained one of the core constituents of his sound. His most famous work is the collection of compositions gathered under the moniker of The Disintegration Loops, which journalist John Doran, in an interview with Basinski for renowned online music magazine The Quietus, describes as "music that speaks directly to what our lives mean in the early $2 \mathrm{I}^{\text {st }}$ century. ${ }^{33} \mathrm{It}$ is this album that will serve as my case study here, for its appeal is linked directly to the unique intersection of time, technology, and aesthetics from which it springs.

${ }^{32}$ John Doran, “Time Becomes a Loop: William Basinski Interviewed," The Quietus, November 20I2, http://thequietus.com/articles/I0680-william-basinski-disintegration-loopsinterview_(accessed 25 March 2019).

33 Ibid. 

in the 1980 os, to a digital format so as to better preserve them (of note here is not only that this attests to a form of tertiary retention, but also that this drive to preserve is itself already necessarily a chronolibidinal desire). In order to achieve this, Basinski ran the loops through a digital tape recorder. In the course of this process, however, the loops slowly disintegrated as a result of the physical contact with the tape head. This caused the music to audibly deteriorate in front of Basinski; as the metal slowly crumbled away, the sound quality of the loops decreased and the music became progressively more muddled and opaque. Basinski was drawn to the deeply haunting nature of the resulting sounds, adapted a number of the recorded loops and released them, to wide acclaim, as The Disintegration Loops (2002), followed by several consecutive albums (adding up to a total of four). The praise bestowed upon these albums-and I will draw on some specific reviews and interviews below-divulged one recurring motif: there was a deep significance to the music's aesthetic of decay. Basinski himself indicates that what appealed to him most intensely in these compositions was the "redemptive quality" 34 realized by the recording process, giving rise to music that was simultaneously dying and surviving. How best to understand the deep significance observed by the albums' extollers and the redeeming virtues that for Basinski stem from the music's twinned logic of survival and death? It will be my argument that these feelings are a direct effect of the manner in which the concepts of chronolibido and autoimmunity are aesthetically grounded in The Disintegration Loops and its technological story of origin.

First of all, to be sure, Basinski is not the first to wrest beauty from the failure of technology. His use of tapes is embedded in a rich musical tradition of exploring a medium's material properties with an eye for points of rupture, elevating technological malfunction to the role of creative wellspring. 35 While this paper is more concerned with the technologically induced effect of Basinski's music than it is with its specific musicological context, it is informative to situate The Disintegration Loops at least somewhat against its musical background. Especially noteworthy is Steve Reich, an

34 Lars Gotrich, "Divinity from Dust: The Healing Power of 'The Disintegration Loops'," NPR Music, November 2012, https://www.npr.org/sections/therecord/20I2/II/I2/164978574/divinity-from-dust-thehealing-power-of-the-disintegration-loops?t=I53I234829316 (accessed 25 March 2019).

35 Caleb Kelly, Cracked Media: The Sound of Malfunction, Cambridge, Massachusetts, The MIT Press, 2009, p. 4. 
absolute pathbreaker when it comes to the creative use of tape loops. Reich is pertinent here not only because of his pioneering practice of tape manipulation, but also for establishing a conceptual framework in which an unintended use of technology comes to signify a means of reflecting on historical tragedy. ${ }^{36}$ Another forebear is Alvin Lucier's sound piece I Am Sitting in a Room (1969), in which Lucier recorded himself reciting a passage, played back this recording into the room he occupied, and then proceeded to re-record it, play it back again, and so on. As the cumulative (re)recordings continue to mesh with the room's unique resonant qualities, Lucier's voice becomes more abstract, overtaken by the sonic atmosphere of the space. Lucier's piece is effectively an exercise in spacing, revealing the alterity that ensues from the coimplication of temporal inscription and spatiality. A third monument of tape loop experimentation that shaped the sonic tradition of The Disintegration Loops is Brian Eno's Music for Airports (1978), a work that Basinski explicitly acknowledges for encouraging him, after having discovered Reich, to further inspect his own feelings of longing and melancholy through his compositions. ${ }^{37}$

There is one other crucial historical element to The Disintegration Loops that must be mentioned here, because it cannot be decoupled from its cultural significance: the album's relation to the events of September II. As the story goes, Basinski was finishing his work on The Disintegration Loops in the weeks leading up to 9/Ir. When the fated day arrived and the planes hit he went up to his New York rooftop and filmed his view of Manhattan: billowing smoke backdropped by a blackening sky. He proceeded to match the video recording to his loops (the album art consists of images taken from the footage), making the events an integral part of the pieces which in turn led to the music becoming something of an unofficial elegy to the day's disasters. ${ }^{3}$ While my interest here is more in how Basinski technologically stages a drama of

${ }^{36}$ Consider, for example, his eschatological composition It's Gonna Rain (1965) and his later work Different Trains (1988).

37 "Fifteen Questions with William Basinski," Fifteen Questions, 2013, https://www.Isquestions.net/interview/fifteen-questions-william-basinski/page-I/ (accessed 25 March 2019)

${ }^{8}$ Jakob Dorof, "William Basinski," Interview, Tiny Mix Tapes, 19 October 2012, https://www.tinymixtapes.com/features/william-basinski\&gt (accessed 25 March 2019). 


\section{(DE)COMPOSITIONS: \\ TIME AND TECHNOLOGY IN WILLIAM BASINSKI'S \\ THE DISINTEGRATION LOOPS (2002)}

temporality, the connection with $9 / \mathrm{II}$ is so inseparable from the pieces that no analysis of the music is complete without at least acknowledging this dimension. ${ }^{39}$

Let me now give a brief description of The Disintegration Loops' first track, $d l p$ I.I, in order to better illustrate the albums' musical characteristics. The piece is written in the key of F major and has a bpm count of 95. The track's most immediately remarkable component is the somber brass melody, slightly over 6 seconds in length, that is looped for the entire duration of the hour-long piece. $4^{40}$ Beneath this loop's undulating waves, however, other elements struggle to take shape; sparse notes carried on strands of static and strings. As the piece progresses, the degradation of the tapes becomes palpable: where the music initially unfolds relatively smoothly, before long the sounds archived on those sections of tape that crumble away fastest clearly begin to fade. Thirty minutes into the piece and we are witness to a stuttering and faltering ensemble, a spectral residue of the tapes' original integrity, rife with the sounds of technological failure. By the end of the piece a mere hum remains, only occasionally disturbed by garbled traces of melody. It must be noted that the track's process of self-erasure is not straightforward: there is no unifying logic to how the disintegration unfolds, because the precise way in which the recorder destroys the tape and the ways the different layers of technology and sound work on one another are uncertain..$^{4 \mathrm{I}}$ The fact that the loops are forced to

39 While situating The Disintegration Loops within the wider field of artistic responses to $9 /$ II exceeds the aims and scope of this paper, it is noteworthy that, while most music dedicated to the events of $9 / \mathrm{II}$ has been composed specifically with the events in mind, the composition of Basinski's loops precedes the date of September II (both in the sense that the original material stored on Basinski's tapes is decades old and in the sense that Basinski had already construed the contraption that produced the disintegrating music). In contrast with a piece like John Adams' famous On the Transmigration of Souls (2012), which was commissioned and composed in specific response to 9/II (names of victims are recounted throughout the piece), Basinski's work predates 9/II and therefore its sonic contents have no direct base in the day's tragedies (this also reveals time's hauntological qualities: no meaning is set in stone and the past can always attain present and future significance in unexpected ways).

40 This is also the formula that defines the albums' other pieces: a relatively short and often forlorn melody is looped for the entire length of the track. All tracks exceed the tenminute mark, and most are well over half an hour long (with the longest track - dip I.I clocking in at 63:33 minutes).

${ }^{4 \mathrm{I}}$ For an excellent musicological analysis of The Disintegration Loops that additionally explains how appearance and disappearance cannot be understood as fully antagonistic concepts, see David Guimond, “The Sounds of Disappearance," Intermédialités, no. I0, 2007, p. II5-I30, https://id.erudit.org/iderudit/I005556ar (accessed 25 March 2019). 
retrace their ruinous path through the recorder creates the impression that the sounds are fighting for survival - they are not allowed to wither away silently, and with each new loop we can hear the music labour harder to assert itself amidst the noise.

The technological apparatus that produced The Disintegration Loops operates according to a principle of death by inscription. That is to say, within the framework of the apparatus, the only way for the analog loops to inscribe themselves as a trace onto the stratum of the recorder, is by opening themselves up to the recorder's disintegrative effects. In fact, it is the very same movement that allows the loops to be exteriorized that also ensures that the loops are stricken by destruction. Here we can see how, within the technological assemblage, the linkage of loops and tape head enacts the logics of spacing and autoimmunity. Spacing, because within the recording process the condition for survival is also the condition for disintegration; the spatial movement of tracing is made possible only through admitting alterity. Autoimmunity, because the assemblage performs the condition of being threatened from within; the loop destroys itself in contact with the recorder in the very same act by which it inscribes itself as a trace.

A second point of relevance concerns the chronolibidinal pathos that the loops elicit. The much-lauded beauty of the loops stems from the recognition of loss inherent to the listening experience- the loops formalize the process of entropy and stage a vigorous negation of the illusion of stability. In keeping with the logic of chronolibido, the promise of loss is here not something to be surmounted, but is integral to the quality of the music: "The obvious observation about The Disintegration Loops is that it's about death, but of course, life gives death meaning." " ${ }^{2}$ Death gives life meaning too, as evidenced by the anecdote Mark Richardson offers to conclude his article on the loops, describing his experience of listening to Basinski's album on the subway, coming down as the loops sputtered their last death rattles: "I was right there with everybody and we were alive." 43 That the loops are decaying is a fundamental part of their appeal. If we recall Hägglund's thesis that when something is on the brink of erasure it can give way to a most profound affective experience, it becomes obvious that the poignancy of the loops is

42 Mark Richardson, "William Basinski-The Disintegration Loops," Pitchfork, I9 November 20I2, http://pitchfork.com/reviews/albums/I7064-the-disintegration-loops/ (accessed 25 March 2019).

43 Ibid. 
made substantially more forceful by the fact that the music announces its imminent demise. ${ }^{44}$ Not only, then, do these loops establish a technological apparatus that materially dramatizes the openness to alterity inherent in the figure of the trace (autoimmunity), but they also emphasize the passionate desire for mortal life (chronolibido). Viewing the loops through the theoretical lens delineated above thus allows us to better understand the cultural significance and appeal of Basinski's piece (and the tradition of which it is part) and, conversely, the piece provides us with a concrete object from whose workings Derrida's and Hägglund's theoretical constructs can be empirically inferred.

A third pertinent dimension underwriting Basinski's music is its relation to the digital. Mark Fisher argues that " $[\mathrm{t}]$ he story of William Basinski's 2002 album Disintegration Loops - a recording of tapes that destroyed themselves in the very process of their transfer to digital - is a parable (almost too perfect) for the switch from the fragility of analogue to the infinite replicability of digital. What we have lost, it can often seem, is the very possibility of loss." 45 The loss of the possibility of loss or of violence would, in keeping with the schema of autoimmunity and chronolibido, be most disastrous, as it would also inaugurate the end of all desire. The notion of the digital as a noiseless realm of infinite replicability, however, is not entirely accurate; digital culture operates according to a logic of creative destruction, planned obsolescence, and systematic updating that complicates ideas of digital fixity. ${ }^{46}$ Regardless, Fisher's account of Basinski's album is instructive here, particularly for how it gestures at the shifting temporal regimes that have accompanied ubiquitous digitization. Fisher draws on Derrida's concept of hauntology and applies it to the realm of music in order to argue that hauntological music has the ability to enact time's disjointed nature. Hauntological artists like Basinski betray a fascination with how "technology materializes memory" (note the links to Stiegler's concept of tertiary retention) and with how technology is able to "invoke lost futures." 47 Seen in this light, The Disintegration Loops is a collection of albums that stages a highly

44 Clune and Hägglund, 2015, p. 120.

45 Mark Fisher, Ghosts of My Life: Writings on Depression, Hauntology and Lost Futures, Winchester, UK, Zero Books, 20I4, p. I44.

${ }^{6}$ Wendy Hui Kyong Chun. Updating to Remain the Same: Habitual New Media, Cambridge, MIT Press, 2016.

47 Fisher, 20I4, p. 2I. 
distinctive experience of time - the process of disintegration proceeds at a slow pace (some of the compositions last well over 50 minutes), which, I argue, gives way to a media experience that is markedly different from the temporal biases of contemporary digital media. This latter predicament is cogently captured by Franco "Bifo" Berardi, who signals a fundamental irreconcilability between the speed at which the digital disperses data and our own neurological capacities for processing information. ${ }^{48}$ The velocities at which our devices can issue demands, present information, generate content, and capture data keep increasing, whereas our own biological constitution bars us from keeping up. Our own temporal registers, in other words, are out of joint with the temporal cadences of the digital, a condition that the temporal media experience offered by Basinski's music forms a critical counterweight to. In the final section of this paper I will further solidify this claim.

\section{NEW MEDia TEMPORALITIES}

Derrida himself already proved quite sensitive to how different media formats induce different temporal experiences in their users. Drawing on the concept of spectrality and its indication of an irreducibly disjointed temporality, Derrida saw the dematerialization that accompanied the rise of (tele)technology as newly shaping our perception of the world:

The virtualization of space and time, the possibility of virtual events whose movement and speed prohibit us more than ever (more and otherwise than ever, for this is not absolutely and thoroughly new) from opposing presence to its representation, "real time" to "deferred time," effectivity to its simulacrum, the living to the non-living, in short, the living to the living-dead of its ghosts. ${ }^{49}$

As the speed at which technology is able to disseminate information increases, our medial experience of time also transforms, a contention that Stiegler has elegantly fleshed out in his work. One example of this transformation is found in the "real time" effect of live television or webstreams, which suggests to the viewer that what is taking place on the screen in front of their eyes is in fact physically taking place at

${ }^{48}$ Franco "Bifo" Berardi, And: Phenomenology of the End, South Pasadena, California, Semiotext(e), 20I5, p. I86.

49 Derrida, 1994, p. 212. 
the exact same moment. Derrida is quick to note, however, that this notion of real time is in essence a technological invention - "if we are going to understand the originality and the specificity of technical modernity, we must not forget that there is no such thing as purely real time, that this does not exist in a full and pure state." ${ }_{5}$ Real time, he suggests, is nothing but "an extremely reduced différance,"si which cannot obliterate the temporal delay inherent in mediation. Indeed, temporalization itself is already divided, which forecloses the existence of a truly isolatable instance of real time; the movement of spacing, in other words, remains constitutive.

This is not to say, however, that this real-time effect, or similar media forms that stipulate a logic of technological acceleration, cannot alter our experience of the temporal. One theoretical concept that can help us get at what is unique about the temporality of contemporary media experience (and what consequently divides it from the temporal expanses offered by Basinski) is Mark B.N. Hansen's notion of "twenty-first-century media." Hansen introduces the concept as follows:

By twenty-first-century media, I mean to designate less a set of objects or processes than a tendency: the tendency for media to operate at microtemporal scales without any necessary — let alone any direct—connection to human sense perception and conscious awareness. [...] For the first time in history, media now typically affect the sensible confound independently of and prior to any delimited impact they many [sic] come to have on human cognitive and perceptual experience..$^{22}$

What Hansen suggests is that human experience is undergoing a rigorous shift informed by the maturation of a mediasphere - dominated by algorithmic and datagathering technologies - that operates according to timeframes fully inaccessible to our own cognitive faculties. As a consequence, we live in increasing awareness that there are innumerable media operations taking place that, while they produce significant effects on our ability to act in the world, leave human perception and consciousness out of the loop. Because twenty-first-century media operate at a

$5^{\circ}$ Derrida and Stiegler, 2002, p. I30.

${ }^{\mathrm{I}}$ Ibid., p. I29.

$5^{2}$ Mark B. N. Hansen, Feed-Forward: On the Future of Twenty-First-Century Media, Chicago, the University of Chicago Press, 2015, p. 37. 
microtemporal scale they transcend our own thresholds for the observation and interpretation of information, leading to a dominant media experience in which time, to rehearse Derrida's Shakespearean motif, is truly out of joint: the "operational present" of our mediascape can only be apprehended in "a future anterior time frame," ${ }_{33}$ meaning that we only have access to these medial operations after they have taken place. The concept of twenty-first-century media addresses this condition and also forms the stage of a critique against Stiegler and the pharmacological tradition he inherits from Plato via Derrida. Hansen argues that the primacy Stiegler lends to a conception of technology as predominantly informing the faculty of timeconsciousness causes his model to miss the abundant media operations that escape "being channeled through higher-order human perceptual experience." 54 Hansen, then, aims to expand the scope of this model, retaining its valuation of human agency, but integrating it into a broader consideration of how media operate and modify experience.

In effect, Hansen's project can be seen as a more affirmative alternative to the work of Berardi. Whereas the latter, like Stiegler, privileges higher-order experience and focuses on the adverse psychopathological effects caused by the myriad digital technologies that accelerate life to a point where people struggle to keep up, Hansen explores new avenues for sensation and experience in the age of twenty-first-century media. This exploration is underwritten by the recognition that today's dominant technological rhythms are punctuated by a beat that is impervious to direct human phenomenological registration. Hansen and Berardi are, however, united in their discernment of a shifting mediasphere - a shifting mediasphere of which, more precisely, the most profound tendencies play out on the level of speed and time. It is in view of this discordance between consciousness and microtemporal technologies that I argue that The Disintegration Loops harbours a third significant temporal dimension.

Mark Fisher analyzed the loops' transfer from analog to digital, and the resultant disintegration, as emblematic of the tension between analog fragility and digital replicability. But instead of reading this shift primarily in terms of a "loss of loss" (a reading that, given the digital's propensity for failure, creative destruction

53 Ibid., p. 25. Of course, as Derrida argues, this belatedness of perception is always the case (because temporal delay is intrinsic to mediation), but the degree to which the temporal scales of our technologies are out of joint with our own experience of time is unprecedented.

54 Ibid., p. 78. 
and corruption, is not entirely feasible), I interpret this shift more in terms of a waning of a particular form of media time. A form of media time, moreover, that is more in line with our own conscious experience of temporality. In slowly destroying the tape loops, the digital recorder gives rise to an object whose temporality is decidedly a-digital. That is to say, while the dominant inclination of twenty-firstcentury media is to expand a microtemporal realm closed off to human consciousness, here we find a composition that is drawn out in contact with the digital, rendering the temporal process of decay fully graspable to the human sensorium.

Fisher's designation of the music as hauntological is pertinent here. In the case of The Disintegration Loops, the disjointed temporality that is endemic to hauntology presents itself in two forms. First, let us recall that hauntological music essentially appeals to Stiegler's idea of tertiary retention; it explores how technology can give form to memory, and in doing so aestheticizes the finite and corruptible (or, in other words, autoimmune) nature of memorization. It communicates that the past is accessible only through traces that are amenable to disintegration; our own fallible and plastic memory, and exterior technical objects that, like Basinski's apparatus, are as susceptible to the law of entropy as we ourselves are. No mode of digital exteriorization can safeguard memory from the mortality that always already haunts it. Second, the disjointed temporality of the music rests in its being antithetical to the microtemporality of twenty-first-century media. If the most significant tendency of digital technologies is indeed their expanding elision of human consciousness, what Basinski's music announces in its contact with the digital is a certain diminution of the power of hauntological music itself. In a sense, the music marks the inadequacy of Stiegler's media-theoretical model and the model of hauntological music when they are confronted with twenty-first-century media; while the former function on the basis of the higher-order faculties of consciousness, memory, and cognition, the latter media forms spread temporal data that can never be consciously experienced, be it in corrupted form or not. The hauntological music that makes up The Disintegration Loops, especially its concrete depiction of the slow degradation of obsolete media formats, invokes a lost future (to borrow Fisher's term) that bespeaks the fading of a mode of experience in which the temporality of hegemonic media formats is less out of joint with our own perceptual registers. Through affording the listener an elongated grasp of a digitally induced destruction, the music plays into what artist Daniel Lopatin sees as the value of "slow modes of listening in an 
otherwise hypersped society" 5 - modes of listening that digress from the everyday cadences of technology and that are thereby able to challenge or reflect on them. The chronolibidinal attachment that these loops facilitate, then, may not only originate in the disintegration of the music itself, but, with it, in the de-centering of a particular model of media time and in the technological corrosion of the music's own conditions of possibility. All of this is not to put a negative spin on Hansen's arguments, as he quite rightly emphasizes that these new media temporalities should not foment anxieties about human obsolescence, but rather to suggest that artworks like The Disintegration Loops, in bringing a unique medial experience of time to the fore, have the power to provoke more general reflections on how technologies are modifying time-consciousness.

\section{CONCLUSION}

In sum, I have argued that Basinski's music discloses a cultural significance that, in light of the relation between time and technology, is threefold. First, the technological apparatus that engendered it enacts the hauntological conditions of the spacing of time and autoimmunity. Second, a significant part of its affective appeal lies in its channeling of the pathos of chronolibido. Third, it offers a form of media experience whose temporality is distinct from the temporal bias that defines the most dominant trends within the contemporary mediasphere. When considered together, these dimensions, and the way they play out in The Disintegration Loops, divulge that the spacing of time is an irreducible condition that is at work in all modes of mediation. The way that time is aesthetically staged, however, is capable of provoking a wide range of emotional responses; while chronolibido in itself does not guarantee any particular response, the way that the imminence of loss is communicated by Basinski's music amplifies the experience of the temporal and the indissoluble union of loss and desire. Furthermore, in the era of twenty-first-century media, where technologies reign according to temporal registers closed off to human consciousness, the narrative behind the music's creation describes a convergence of the digital and the analog that negates this dominant medial tendency towards microtemporality. Almost two decades after their birth, Basinski's loops and their technologically informed dramatization of the workings of time thus feel more theoretically pertinent than ever.

55 Simon Reynolds, Retromania: Pop Culture's Addiction to Its Own Past, London, Faber and Faber, 20II, p. 352. 


\title{
(DE)COMPOSITIONS: TIME AND TECHNOLOGY IN WILLIAM BASINSKI'S THE DISINTEGRATION LOOPS (2002)
}

\author{
JAKKO KEMPER, UNIVERSITY OF AMSTERDAM
}

\section{ABSTRACT}

This paper analyzes William Basinski's album The Disintegration Loops (2002) and argues that its aesthetic rendition of temporality and finitude is relevant in view of the relation between technology and the human perception of time for three reasons. First, the technological apparatus responsible for its creation mirrors the Derridean concepts of the spacing of time and autoimmunity. Second, the album's affective appeal illustrates Martin Hägglund's notion of chronolibido. Third, the music gives rise to a temporal media experience that exists at odds with the media experience afforded by what Mark B.N. Hansen has described as twenty-first-century media. Together, these three dimensions make The Disintegrations Loops an object that allows for an empirical grounding of the discussed theorizations of time and media.

\section{RÉSUMÉ}

Cet article analyse l'album The Disintegration Loops (2002), de William Basinski, et soutient que son interprétation esthétique de la temporalité et de la finitude est pertinente au regard de la relation entre technologie et perception humaine du temps pour trois raisons. Premièrement, l'appareil technologique responsable de sa création reflète les concepts derridéens d'espacement et d'auto-immunité. Deuxièmement, l'appel affectif de l'album illustre la notion de chronolibido de Martin Hägglund. Troisièmement, la musique donne lieu à une expérience médiatique temporelle qui contraste avec l'expérience médiatique offerte par ce que Mark B.N. Hansen appelle les «médias du $2 \mathrm{I}^{\mathrm{e}}$ siècle ». Ensemble, ces trois dimensions font de The Disintegration Loops un objet qui permet de donner une base empirique aux théories discutées du temps et des médias.

\section{BIOGRAPHICAL NOTE}

JAKKo KeMPER is a PhD candidate at the Amsterdam School for Cultural Analysis (University of Amsterdam). His research focuses on the aesthetics of imperfection, digital culture, and media theory. He has previously published in Information, Communication ES Society. 